\title{
THE SOCIAL \& MOBILE LEARNING EXPERIENCES OF STUDENTS USING MOBILE E-BOOKS
}

\author{
Jeff S. Kissinger \\ Florida State College
}

\begin{abstract}
This research was designed to explore the learning experiences of state college students using mobile electronic textbook (e-book) readers. The purpose of the study was to build a rich description of how students used e-books delivered on mobile computing devices for college-level, introductory sociology courses at a public state college in the southeastern United States. This research employed a multiple case study design that investigated and documented student experiences with this instructional technology.

The bounding frame was comprised of the literature on mobile technology, mobile learning theories, and e-books. A theoretical lens of learning theories commonly found in the literature on mobile learning (constructivism, social cognitive theory, self-efficacy theory, expectancy x value theory, selfdetermination theory, and situated cognition) was situated within the mobile learning framework. The theoretical lens was used to provide insight to the student's learning experiences.

Six conclusions were drawn from the study: (1) students expressed competence in their use of the mobile e-books, (2) students expressed feelings of high self-efficacy when using the mobile e-books, (3) students valued the use of the mobile e-books for their learning, (4) students were individualized and metacognitive in their learning with the mobile e-books, (5) students enhanced their learning socially and within situated learning opportunities, and (6) the students and the instructor had divergent views on the value and utility of social, interactive textbooks.
\end{abstract}

\section{KEYWORDS}

mobile learning, social learning, social networking, Facebook, e-books, social cognitive theory, expectancy $\mathrm{x}$ value theory, situated cognition, situated learning, metacognition, self-determination theory, textbooks, faculty views on mobile learning, student views on mobile learning

\section{INTRODUCTION}

U.S. higher education institutions are currently in a climate of increasing government calls for accountability, while funds diminish. Contributing to this climate, textbook publishers are producing more frequent editions to already costly course texts and materials that are increasing the overall cost of college attendance for students [1]. Most recently the 2012 Educause report "Seven Things You Should Know About eBooks" focused on practical challenges, current pilots, and the significance of the change from traditional print textbooks to e-books. This study addressed the most urgent question that the report asks, "What are the implications of transitioning to e-books for teaching and learning?" [2].

New technological innovations in the consumer market, such as increased availability of electronic texts - for example, hardware e-book readers and large text collections on the Internet - also have gained momentum. Within this overall climate some higher education institutions are considering a move to using all electronic textbooks and materials, as an option to cut costs and to ensure student access to affordable college educations. While that move could reduce textbook costs, the ways that the transition to mobile e-books will impact student learning are unclear, and researching the issue will ensure that students are positively served through the transitions. 


\section{A. Background of the Problem}

Higher education institutions are beginning to explore e-book and e-book reader use in learning environments $[3,4,5,6]$. The current Princeton University study employs the Amazon Kindle DX ebook reader. Likewise, the four goals of the Princeton pilot program are that (a) there would be no sacrifice in the classroom experience due to technological intervention, (b) the use of an e-reader would offer convenience to course participants, (c) the desire to print or photocopy would be reduced, and (d) the unique strengths of current e-readers would be explored. At Arizona State University and Northwest Missouri State University challenges already have emerged, such as accessibility for students with visual disabilities and student dissatisfaction with various functionalities, such as highlighting. Additionally, many of the first e-book readers such as the Kindle were not fully ADA accessible, an overall concern that remains with e-readers.

The 2011 and 2012 New Media Consortium think tanks have predicted and heavily emphasized the significance that mobility and e-books will have on teaching and learning. If their findings are true, then more data and pilots are needed, to uncover the implications for teaching and learning, challenges, obstacles, and potential novel benefits $[7,8]$. Increasingly flexible and mobile distance learning methodologies are emerging that can be utilized for technology access-challenged student populations; however, significant data on issues related to teaching and learning in this fashion is lacking $[9,10]$.

In the fall of 2011, Florida State College at Jacksonville (FSCJ), formerly Florida Community College at Jacksonville, planned to transition from paper-based textbooks to electronic textbooks for many of its 100- and 200-level courses. As part of the college's SIRIUS Academics initiative, a college course design and textbook-publishing consortium, FSCJ would no longer print and sell paper-based versions of SIRIUS Academics course textbooks. As a measure based partly on reducing textbook costs to students and on making college education more affordable and accessible, students receive course textbooks in an entirely electronic format that can be used online and on mobile e-book reading devices. This study investigated the experiences of college students using dedicated digital e-book readers in undergraduate introduction to sociology courses. The ways that students used these devices and e-books was the focus of the research, in an effort to better understand the students' learning behaviors in a college course that employed these emerging educational technologies.

\section{CONCEPTUAL FRAMEWORK}

The literature framing this study pertained to mobile learning, e-books and e-readers, and mobile learning theories. The theoretical lens informing this study (Figure 1), its methods, and its strategies for analysis was comprised of constructivism, social cognitive theory, self-efficacy theory, expectancy-value theory, self-determination theory, and situated cognition.

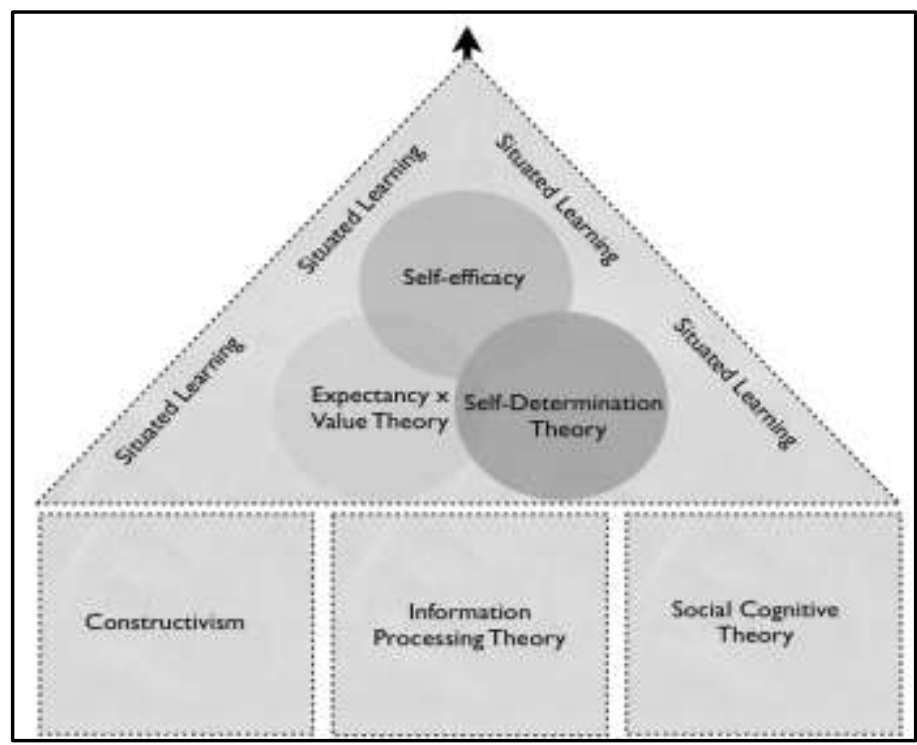

Figure 1. Mobile eBook Learning Experience Framework 


\section{B. Constructivism}

In their emerging research, mobile learning theorists have focused on the unique affordances that mobile technology and learning applications have made possible $[10,11]$. Combined with the individual and personal nature of portable computing devices, mobile learning is perhaps uniquely suited for constructivist learning scenarios. An example of this may be on-demand information and knowledge access in the learner's authentic environment, facilitated via a mobile computer or e-book that learners use to augment their daily experiences and ultimately construct their own meanings and understandings [21, 22]. Zurita, Nussbaum, and Sharples have advocated the use of mobile technologies in pedagogical designs to foster more constructivist types of teaching and learning [23]. In their experiment with a constructivist learning environment employing wireless mobile technologies, they found that the positive learning results were greater in that situation than in a constructivist learning environment without the use of the mobile technology. For the present study, students using mobile e-book readers were situated within constructivism, and the broad theoretical notion that individuals create their own mental understandings of their experiences within the world around them.

\section{Information Processing Theory}

One of the cognitive learning theories developed in recent times is information processing theory $[20,24]$. Information is taken in or perceived by senses such as sight, smell, hearing, or a combination of these. The information is then processed in working memory, where information is rehearsed and either moves onto the next stage in the model or is lost [25]. If information is rehearsed and eventually encoded, it will then be stored in long-term memory [17]. In long-term memory, the information can be retrieved for later use or supplemented with the addition of new information.

A frequently touted potential benefit of mobile devices has been their portability, which allows for more learned-centered and situational learning experiences $[13,17,26]$. However, some researchers have found evidence pointing to the limits of working memory with mobile-learning scenarios [27].

\section{Working Memory}

As some researchers have investigated, one's working memory capacity may influence learning in a mobile-learning scenario. For example, the undergraduate students in Doolittle and Mariano's study recalled less when they learned a lesson on a mobile device while walking around campus. Because students' working memories were divided in that experiment, their attention on the instruction was diminished [27].

\section{Automaticity}

Further related to working memory is the construct of automaticity, the ability to conduct tasks or mental operations with significantly less mental effort and working memory allocation [29]. Students' use of e-books on mobile learning devices probably will be impacted by the extent to which their use consumes working memory. Consequently, how students use mobile devices, and in what contexts, will further add to the understanding of mobile learning.

\section{Metacognition}

Essentially, metacognition is a person's knowledge about his or her learning and the related processes. For example, if students feel that listening to music while reading or studying for a test distracts them, then they may avoid studying in common areas. This example demonstrates students acting on their own metacognition and beliefs about learning, and such metacognitive strategies result in higher individual student performance [31].

\section{Social Cognitive Theory}

As some researchers in mobile learning have noted, this interplay of learners, their environments, and their actions make mobile learning unique and potentially powerful [10,13,35]. Novel ways of learning afforded by the location-agnostic mobile computing device, which frees learners to learn anywhere, anytime, is at the core of mobile learning research. In their work toward developing a theory of mobile learning, Sharples et al. viewed the type of learning and behaviors afforded by portable mobile technologies as highly personal and situated within the individual's own authentic 
contexts $[14,17]$. This present study focused on how the students used mobile learning technologies, thus investigating the interplay of the learner and the environment, as well as the situational aspects.

\section{Self-efficacy}

A subset of social cognitive theory is self-efficacy, a theory that attempts to explain learners' feelings and perceptions of their performance abilities and their choices to take actions based on these [34]. Based on the self-efficacy research regarding learning and use of computers, students with higher degrees of self-efficacy related to the use of the mobile e-books might be expected to experience greater course outcomes and a higher degree of satisfaction [36, 37, 38, 39]. However, Wang and Wang, in their work on developing a mobile computing self-efficacy scale (MCSE), expressed that the use of mobile devices is unlike generic technology or the Web, and therefore should be studied independently [40]. Wang and Wang stated, "a comprehensive MCSE instrument can provide a more accurate diagnostic tool to assess an individual's mobile computing self-efficacy than can a simple adaptation of computer self-efficacy or Internet self-efficacy scale" [40]. Building on Wang and Wang's case for studying the specific, unique aspects of mobile computing, this collective case study also attempted to explore students' self-efficacy beliefs regarding the mobile e-book technologies, as well as how technology might affect students' behaviors and outcomes in the course.

\section{Expectancy $x$ value theory}

Expectancy $\mathrm{x}$ value theory is related to self-efficacy theory. Expectancy $\mathrm{x}$ value theory provides a theoretical construct regarding motivation and the variables comprised within an individual's choices and his or her likelihood of achievement [42]. In regards to the present study, this theory of learner motivation further enhances the conceptual lens through which to examine student learning with ebook technology.

\section{Self-determination theory}

Related to both self-efficacy and expectancy $\mathrm{x}$ value theory is the theory of self-determination, which is seen by some as a theory that incorporates both models, because it includes both intrinsic and extrinsic motivation [32]. Ryan and Deci explained that autonomy can increase individual intrinsic motivation and influence subsequent achievement. Ryan and Deci's research on self-determination theory also indicated that, combined with autonomy and competence, individuals are more likely to be intrinsically motivated when tasks are need related [43].

\section{E. Situated Cognition}

Drawing on both constructivism and social cognitive theories, situated cognition focuses on the context in which activities occur and their application to real-world use [17]. Situated cognition furthers the belief that knowledge and the acquisition of knowledge cannot be separated from the environment in which they are used. The key components of situated cognition reside within the authentic context and purpose for which new knowledge is gained and used.

Some researchers have taken issue with situated cognition's reliance on environmental variables, questioning whether learning is fundamentally bound to a particular context in time, and further arguing that abstract knowledge can be gained through both concrete and abstract examples [48]. However, researchers in mobile learning have focused heavily on the environment, social negotiations, and authenticity of the uniquely-situated learner $[10,13,36]$. The present study also investigated the situated learning contexts of students using mobile e-books.

Due to the context-agnostic nature of mobile learners and portable technology, such as e-book readers, situated cognition was an ideal constructive theoretical stance in which to ground this inquiry, because it focused the inquiry on learners within their authentic, individual environments. Much research on mobile learning has focused on the technology itself, rather than its use for learning, and researchers in mobile learning have called for a shift in the research agenda to the learning $[10,49]$. Despite a movement in this direction, still more recent collections of cases are more focused on technology and course design versus in-depth inquiries into teaching and learning [50]. To this purpose, this study focused on several research questions about learning. 


\section{F. Mobile Learning \& E-books}

Mobile learning, also called mLearning, is the use of mobile, portable, and hand-held computing devices in learning applications and environments [51,52,53]. Traxler defined mobile learning from the perspective of the technology: "any educational provision where the sole or dominant technologies are handheld or palmtop devices," but further added that the learner may also need to be centered in a definition [12,54]. This learner-centered move in the research has been most widely promoted by Sharples et al., who considered actual learners' contexts and experiences paramount [10].

The dominant focus of most mobile learning research has been on the technology and its usability and features, rather than within a broader pedagogical framework [55]. By studying mobile learning applications and use within learning theory frameworks, such as Waycott's use of activity theory, researchers can better understand possible transformational influences and the actual learning of mobile learning $[35,56]$. In Sharples et al.'s formative theories on mobile learning, they moved the research agenda away from the dominant "technocentric" focus on the mobile technology and back to the learners, their contexts, and the unique potential affordances of emerging mobile practices in education $[10,22]$.

As Cheung and Hew pointed out, the majority of the research has been limited in its scope [55]. They, along with other researchers, including Sharples et al., advocated research theoretically grounded in topics related to pedagogy [10]. Specifically, Cheung and Hew stated, "The use of theoretical foundations will help inform the pedagogy of using them - a key success factor to the successful use of mobile devices to enhance learning" [55]. While some research examples of this move to more pedagogically-framed inquiries exist, more research in this vein is needed, to explore possible positive and challenging aspects facing the learner in mobile learning scenarios $[35,50,57,58]$.

Many researchers have touted the potential of mobile learning to promote new learning opportunities and expanded lifelong learning, and specifically have championed the mobility aspect of mobile learning, in terms of the potential of more authentic, learner-centric contexts.

However, researchers must be diligent and careful not to let this mobile learning potential influence their research or agenda in overly optimistic terms $[10,35,59,60]$. In an experiment involving working memory capacity and multimedia lessons on an iPod, conducted with university students as subjects, Doolittle and Mariano found that students using the multimedia lessons in a stationary context-i.e., in a classroom setting - performed better on post-lesson assessments than students that viewed the lessons on the iPod while walking around the university campus [27]. That study was unique in that it highlighted one potential weakness in mobile learning scenarios. More importantly, the study underscored the need for additional research, grounded in pedagogical frameworks, to explore all facets of students learning with mobile technologies. Understanding students' learning and the unforeseen factors, both positive and negative, will better inform educational researchers, designers, and leaders.

\section{RESEARCH QUESTIONS}

Primary Question: What were the learning experiences of students using mobile e-books in online and classroom-based introductory sociology courses?

Subquestion A: What factors contributed to students' successful use of mobile e-books to support their learning?

Subquestion B: What factors inhibited students' successful use of mobile e-books to support their learning?

Subquestion C: What changes to mobile e-books did students want that would best support use of these devices for learning?

\section{METHODOLOGY}

Because mobile learning is a relatively new model for delivering courses, little research exists on how best to design and deliver these courses. Dominated by a technocentric research agenda, existing inquiries have focused on the mobile devices themselves, infrastructure, and usability, not learning [49]. However, inquiries related to teaching and learning are also needed $[9,10]$. In one of the most comprehensive collections of research on mobile learning, Mobile Learning: A Handbook for Educators and Trainers, the authors compiled 12 case studies related to mobile learning [49]. The 
authors called attention to the need for inquiry regarding the best mix of teaching methods and technologies, so future researchers can promote effective mobile-learning scenarios. Furthermore, in a report on emerging research issues in mobile learning, "Big Issues in Mobile Learning," researchers Sharples, O'Malley, and Taylor emphasized a shift of the agenda away from examining the mobile devices and back to teaching, the learners, and the learners' perspectives [61]. A research agenda that informs the teaching and learning aspect of mobile learning is needed, and that agenda was the guiding principle of this qualitative design.

A qualitative approach was best aligned with this study, to fulfil the purposes of particularization versus generalization. From authentic participant voices, artifacts, and real-life events, a detailed record of students' mobile learning experiences was constructed. The collected data were understood through the theoretical framework established in Section II.

This study's epistemological approach was grounded in a naturalistic and constructivist research paradigm, focused on the particular contexts and experiences of individuals' cases, which served as the repository for in-depth mining of qualitative data based on real lives and events [62]. These data helped accomplish the overriding goal, to further educational leaders' and researchers' understanding of actual, lived experiences of students using mobile technologies for their learning. A collective case study approach was employed to accomplish this purpose [63].

\section{G. Setting and Participants}

The participants for this collective case study were undergraduate students at Florida State College at Jacksonville (FSCJ), a large college in the southeastern United States. The setting was appropriate because the college transitioned to completely electronic textbooks for most of its institutionallypublished course materials during the 2010-2011 academic year.

\section{H. Data Sources}

To build the case records and database that informed understandings of students' mobile e-book learning experiences in this collective case study, data were collected from multiple sources [64]. Yin referred to a convergence of evidence in data collection efforts, as researchers draw on multiple data sources to employ in triangulation analysis techniques, which aim to corroborate facts and phenomenon [65]. This study was comprised of both archival data and data that were collected after approval of the full research protocol by the University of North Florida's IRB.

\section{Archival Data}

Thirteen students using the e-books in both the online and face-to-face sections maintained written journals. Two-part, open-ended writing prompts were e-mailed to the student volunteers every week, asking them to record their thoughts, feelings, and experiences using the e-books. These journals were submitted as secure text documents through the Blackboard ${ }^{\circledR}$ learning management system (LMS) to an e-book community established for that purpose. Each of the 13 student volunteers completed 9 journal entries. The self-reported student data were added to the collective case study database after the study was approved, and students provided informed consent for these materials to be included in the present study.

In addition to the student journal data, any available archival data were retrieved from student e-book notes. With the ASUS ${ }^{\circledR}$ Eee PC ${ }^{\mathrm{TM}}$ 1005HA netbooks, through MyScribe ${ }^{\mathcal{O}}$, students could record and save their notes directly into the e-book. These notes could be compiled and used for reviewing, studying, or sharing. For the three students who used this functionality, these data were collected from the ASUS $^{\circledR}$ devices and added to the case study database. The Sony ${ }^{\circledR}$ PRS-505 Reader had no equivalent feature; therefore, these types of data were not collected from those devices.

\section{J. Data Collection}

The final and most extensive step in the data collection involved conducting qualitative in-depth interviews with 7 out of the original 13 students who agreed to participate. The interviews were semistructured and open-ended, designed to uncover students' actual mobile e-book course experiences related to their learning [66]. The question prompts were designed to enlighten the understandings of student e-book use within a constructivist, social cognitive, and situated learning framework. Students were asked to explain how and where they used their mobile e-books, providing details of any 
common or novel applications during their courses.

In addition to student interviews, the instructor participated in semi-structured interviews. The purpose of these interviews was to further enhance the overall case record and to triangulate with the other data sources. The instructor interview and all student interviews were recorded, transcribed, and added to the case study database.

Table 1 delineates information regarding the seven student volunteers' demographics, chosen devices, and course types.

\begin{tabular}{lllll}
\hline Name & Gender & Age & Device & Course Type \\
\hline Student A & Male & 24 & ASUS $^{\circledR}$ Netbook & Traditional \\
Student C & Female & 21 & Sony $^{\circledR}$ Reader & Online \\
Student D & Female & 20 & Sony $^{\circledR}$ Reader & Online \\
Student K & Male & 24 & ASUS $^{\circledR}$ Netbook & Traditional \\
Student M & Female & 42 & ASUS $^{\circledR}$ Netbook & Traditional \\
Student R & Male & 23 & ASUS $^{\circledR}$ Netbook & Online \\
Student T & Female & 59 & ASUS $^{\circledR}$ Netbook & Online \\
\hline \multicolumn{2}{c}{ Table 1. Student Demographic, Device, and Course Information }
\end{tabular}

\section{K. Data Analysis Summary}

Employing the general analytical strategy of relying on theoretical propositions, the data collected in this study were examined through various methods and techniques chosen for their abilities to enhance understanding [65]. These included constant comparative analysis, open and axial coding, and Yin's analysis techniques - pattern-matching and cross-case synthesis [65,67]. The overall purpose of the chosen data analysis strategies and techniques was to develop insight to the students' learning experiences with mobile e-books.

The information gathered in the collective case study database was analyzed on three levels:

Level 1: student case descriptions,

Level 2: interview excerpt topical categories, and

Level 3: thematic cross-case syntheses.

\section{Student Interview Transcript Coding}

All of the students' interview transcripts were coded into seven primary categories. These categories were based on the study's theoretical framework or were derived after the interview transcript review. The categories based on the theoretical framework are social constructivism, self-efficacy, and situated learning; categories based on interview transcripts are acceptable social use, personal learning environments, student e-book activities, and student motivations. In addition to the seven primary categories, a combination of categories derived from the theoretical framework and unique categories extracted from the data analysis emerged.

\section{DATA ANALYSIS}

\section{A. Summary of Level 1 Data Analysis}

The first level of data analysis for this study examined students' general demographic information, familiarity with mobile e-books prior to the study, as well as initiating an exploration of themes that emerged from students' interviews. These themes were coded to reveal various topical categories, some of which were identified in the theoretical framework and some of which were novel. Novel categories that emerged during the coding process were selected for their ability to address the overriding research questions and purpose.

\section{B. Summary of Level 2 Data Analysis}

The level 2 data analysis contained student interview text excerpts that were organized within coding categories established during the level 1 data analysis. These student interview transcript texts comprised the qualitative data that was analyzed through grounded theory procedures. This process involved selecting text and passages and organizing them into thematic codes that aligned with the 
constructs of the theoretical framework of this study, such as metacognition, and novel categories, such as acceptable social use. These thematic code categories included acceptable social use, personal learning environments, emotional media, expectancy x value theory, metacognition, e-book activities, self-determination theory, self-efficacy, situated learning, social constructivism, and usability. These thematic categories, as well as their corresponding subcategories, are listed in Table 2.

\begin{tabular}{ll}
\hline Categories & Subcategories \\
\hline Acceptable Social Use & - \\
Personal Learning & - \\
Environments (PLEs) & \\
Student E-book Activities & Printing \\
& Highlighting \\
& Key word searches \\
Student Motivations & Competence \\
& Value \\
& Persistence \\
& Time urgency \\
& Difficulty of use \\
Self-efficacy & Confidence \\
& Sources of confidence \\
& Previous technology experiences \\
& Student claims of no e-book interactions with other \\
Constructivism & students \\
& E-book use to support online discussions \\
& Desire for social learning textbook \\
Situated Learning & Anytime, anywhere learning \\
& Disruptive locations \\
& Cognitive load \\
& GPS textbook analogy \\
& Situated learning instructional design \\
\hline
\end{tabular}

Table 2. Thematic Categories and Corresponding Subcategories

\section{Summary of Level 3 Data Analysis: Thematic Cross-Case Syntheses}

The purpose of the third and final level of analysis was to address the study's three subquestions of this study, which examined factors contributing to and inhibiting students' successful use of mobile ebooks to support their learning, in addition to what changes to mobile e-books students felt would best support their use of these devices for learning.

\section{Research Subquestion A: What Factors Contributed to Students' Successful Use of Mobile E-books to Support Their Learning?}

Three main factors emerged from the data that created increased understanding of this question for these students using mobile e-books: nonlinear use, mobility, and situated learning. Nonlinear use transpired when students described instances where they used the e-book in a nontraditional way-for example, skipping around a chapter instead of reading it from beginning to end. While traditional, print textbooks also can be used in a nonlinear fashion, the students in the study described how they used unique features of the e-books that increased nonlinear usage, particularly the search and bookmarking functions.

Related to Student A's perspective on the perceived mobility benefits was the perceived learning value placed on the affordance of situated study within his everyday life, such as in bookstores and coffee shops. Student A felt that his learning was enhanced by this mobile affordance of allowing his reading and learning to take place where he chose, describing how he felt he experienced deeper engagement with sociological concepts by witnessing them in the world and discussing them with people in his environment. 


\section{Research Subquestion B: What Factors Inhibited Students' Successful Use of Mobile E-books to Support Their Learning?}

Based on the data, two main factors enhanced understanding of the factors that inhibited students' successful use of mobile e-books to support their learning: perceived value of the e-book and mobility. One student did not persist, due to a misconception about the e-book and the low value she placed on its use for her learning. Moreover, some students described mobility as a positive influencing factor for their learning, while others saw this same factor as a negative factor.

\section{Research Subquestion C: What Changes to Mobile E-books do Students Want That Would Best Support Use of These Devices for Learning?}

In addressing the question about what changes to mobile e-books students wanted - changes they felt would best support use of these devices for learning - four factors were identified. These ranged from issues in basic usability, such as print functionality, to more learning-oriented concerns, such as the concept of a social textbook (that is, one that is interactive and collaborative). The four factors were removing restrictions, adding advanced searching, providing a short user guide, and providing an interactive social learning function.

\section{CONCLUSIONS}

Six conclusions were uncovered through the three levels of data analysis, and all conclusions related to the study's primary research question and corresponding subquestions. These conclusions are as follows:

Students expressed feelings of competence

Students expressed feelings of high self-efficacy

Students valued using the e-books for their learning

Students perceived e-book use as metacognitive and individualized

Student use demonstrated that e-books can enhance learning

Student and instructor views on the learning value of social texts diverged

\section{A. Students Expressed Feelings of Competence}

In response to Research Subquestion A-what factors contributed to students' successful use of mobile e-books to support their learning? - students reported that they competently used their ebooks. The students in this study received no formal instruction on using the e-books, regarding how to turn the devices on or how to navigate in the e-book itself. Students were simply provided the device of their choice to use. Usability did not emerge as a problem or hindrance in this study, as students expressed a universal competence in their abilities to use the e-books. Likening the e-books to laptops, televisions, and other familiar technology, students apparently were able to generalize these past experiences to the e-books.

\section{B. Students Expressed Feelings of High Self-Efficacy}

Also in response to Research Subquestion A-what factors contributed to students' successful use of mobile e-books to support their learning? - all of the students in this study expressed feelings and perceptions of high self-efficacy. Students universally expressed beliefs of being empowered and in control, and they expected to be successful in using the e-book for their learning. While some students did express a short "warm-up" period when initially using the ASUS ${ }^{\circledR}$ netbook and Sony ${ }^{\circledR}$ e-book reader, they quickly started using the e-book successfully and continued to use it throughout the course.

As for the instructor in this case study, his early interview comments characterized self-efficacy as a "learning bump" that needed to be overcome before students could get on to the business of his class and learning about sociology. His comments supported the notion, advanced by Wang and Wang, that self-efficacy in mobile learning is a fundamental construct that must be addressed before students can focus on their learning [40].

Within this collective case study, all students were found to have feelings of high self-efficacy using their mobile e-books for their learning. However, those perceptions did not always result in persistence in e-book use or overall success in the course. For example, despite describing feelings of 
high self-efficacy, Student M stated that she stopped using the ASUS ${ }^{\circledR}$ netbook e-book after 3 hours, instead resorting to the traditional print textbook. During the instructor interview, he shared that this student did not pass the course and had actually stopped attending class. Apparently, for this student, her overall learning experience was not ideal. The cause for the student's abandonment of the course was unknown, but evidence as to why she did not persist in the use of her e-book was revealed, which pertains to the next major conclusion of this study, student value of e-book use.

\section{Students Valued Using the E-books for Their Learning}

In addition to students' perceptions and feelings of high self-efficacy in using the e-books for their learning, all but one student expressed the positive value of using the e-book. This factor and conclusion enlightens Research Subquestion A-what factors contributed to students' successful use of mobile e-books to support their learning? - and Research Subquestion B: what factors inhibited students' successful use of mobile e-books to support their learning? The students' learning experiences with the mobile e-books is best understood when viewed through the theoretical framework of this study, and particularly by employing expectancy $\mathrm{x}$ value theory.

Expectancy $\mathrm{x}$ value theory on learner motivation and persistence, while related to self-efficacy, is better-suited for enhancing understanding of the learning experiences of the students who valued and persisted in using the mobile e-books. Students interested in particular topics in sociology may be more motivated to read these in a textbook. Related to self-efficacy, the learner's perceived importance of a task is related to his or her self-concept and his or her ability to complete the task successfully. The utility value of a task is the extent to which completing the task will benefit the learner in reaching a certain goal. An example of utility value is the perceptions of students' use of the e-book as a beneficial learning tool.

Lastly, the cost of a task is the negative side of participating in a behavior. If students feel the e-books are too difficult to use and master, they may not persist and may instead resort to a method that is perceived to have less associated cost. The fact that all but one student valued the use of the e-book illustrated that the students felt the technology was useful and helpful for their learning in the course. The factor of e-book value and associated cost was revealed as a factor that could contribute to or inhibit students' successful use of e-books. Further studies on student motivation for using the ebooks - in particular the factors of student-perceived value and cost - may increase understanding of why some students would choose to successfully use this technology for their learning and why others would choose not to persist.

\section{Students Perceived E-book Use as Metacognitive and Individualized}

Addressing Research Subquestion A-what factors contributed to students' successful use of mobile e-books to support their learning? - the fourth major conclusion that emerged from this study was that students were individualized and metacognitive in their e-book use. Mobile devices, unlike traditional computers, have been found to be regarded as more personal by users $[14,15]$. This may begin to explain why students in this case study, while describing similar uses of their e-books, also reported individual e-book uses that they felt best supported their learning in the course.

Students C, D, and K all expressed that they used the e-book as a music device. Some explained, as Student $\mathrm{C}$ did, that this was a way to minimize learning distractions. Whether on a road trip to a sister's wedding or on campus in between classes, these students described instances of enhancing their concentration with the e-book by using it with music. Information processing theory is a key to understanding the learning experiences of students in these examples with music. These students, by describing how they enhanced their ability to concentrate, read, and study with the e-book, exercised their metacognition about their own understandings of how they learn best — by using the e-book with music. The students augmented their surroundings to create personal learning environments that they thought would best support their learning.

All students in this case study gave examples of how they used the e-books' various functionalities, like searching and bookmarking, to best support their learning. Some students expressed individual, metacognitive epiphanies, such as when Student $\mathrm{T}$ discussed how the key word searches provided multiple benefits for her. This functionality saved her time, allowed her to be more efficient as she participated in the discussion boards, and helped her review the course concepts with more depth and understanding. Student T explained that because searching was quick and efficient, she found herself 
taking the time to review the concepts, instead of guessing. She referred to this as "constant reinforcement," as she read and reread passages in her text, and looked up concepts and definitions while she completed the online quizzes and discussions.

Similar to Student T's use of key word searches, Student C expressed that using bookmarks in the Sony ${ }^{\circledR}$ e-book reader increased her learning interactions in the online discussion boards. She compared using the bookmarks to a hard copy of text; with the hard copy, she would have to flip through pages to find information. However, the bookmarks in the e-book saved her time, and she then used this time to revisit the online discussions and help her classmates by providing information from the e-book. Student $\mathrm{C}$ was metacognitive in her thinking regarding not just her own learning but also regarding how her extra participation in the discussion would enhance the overall learning of her class.

Related to purposeful and individual e-book use, students also took time to consider their environments and social contexts. Student A, in particular, was contemplative while discussing how he used the ASUS ${ }^{\circledR}$ netbook e-book in public, at a local bookstore with a friend. He described how he felt that using his e-book in public raised fewer social barriers, as opposed to a traditional, print textbook. Student A felt that he could be more discrete with the e-book, but still make use of his time there to learn and participate in his class.

Like Student A, Student C's experience using her Sony ${ }^{\circledR}$ e-book reader in the hospital provided an example of metacognitive e-book use. She related the story of quietly using the e-book with one hand, while her baby slept in her other arm. Student $\mathrm{C}$ explained that the e-book afforded her the ability to discretely read while waiting to see her doctor; she enjoyed that no one could tell what she was doing, which could have had the benefit of minimized social interactions and disruptions. Both Student A and Student $\mathrm{C}$, in their personal methods, exercised knowledge and behaviors about using their ebooks. Student C, however, appeared to have more distinctly practiced metacognition, based on her cognitive beliefs about her learning with the e-book.

The various examples detailed in this section, such as listening to music or considering environmental and social aspects of e-book use, demonstrated how student learning experiences in this case study were personal and perhaps metacognitive. This metacognition contributed to students' successful use of the mobile e-books. In addition to these metacognitive uses of the e-book, students augmented their learning by choosing their individual learning contexts, which corresponds to how mobility affords enhanced learning experiences, the next major conclusion that will be discussed.

\section{E. Student Use Demonstrated That E-books Can Enhance Learning}

E-book use as a learning enhancement relates to Research Subquestion A-what factors contributed to students' successful use of mobile e-books to support their learning? - and the primary research question: what were the learning experiences of students using mobile e-books in online and classroom-based introductory sociology courses? Drawing mainly on research in situated learning, Sharples et al. and others contended that through mobility, learners may experience more contextualized, authentic learning opportunities that transcend those typically available within the confines of a classroom $[10,12,17,54]$.

Student $\mathrm{T}$ said that she primarily chose to use her e-book at home, which for her was the most comfortable location and one that had the fewest distractions. Student A preferred to use the e-book while in public, such as at a local bookstore with friends. Both Student T and Student A expressed their sense that where they used the e-book impacted their ability to learn effectively, demonstrating metacognition in their choices. In these two cases, students expressed a level of metacognition, where they thought the location of their e-book use had the ability to positively or negatively influence their learning.

While there may be great potential in exploiting the situated nature of mobile learning applications, limited studies have stated a need for caution. In particular, one study on the working memory constraints of students suggested that the mobility of mobile learning for college students could negatively impact learning recall [27]. Within the present multiple case study, the instructor expressed strong reservations and skepticism about the potential for mobile learning to produce higher-level learning through situated cognition, even though this concept remains a prominent theme in current research pertaining to this aspect of mobile learning $[10,35,59,68]$. In this collective case study, students described examples where they thought their learning was enhanced through firsthand 
observations while studying in particular environments. In particular, Student D took the suggestion of the textbook and its designers to become an amateur sociologist and observe her surroundings, to look for concrete examples of the abstractions contained within the text. Students A and R also gave examples of how this situated influence supported their learning.

Nevertheless, some students, such as Student T, raised concerns about the challenges of using the ebook in certain contexts they found distracting, like their work environments; these concerns were echoed in the instructor's interview comments. Students mentioned disruptions that caused constraints on working memory, which impacted student learning outcomes [27]. Therefore, while some students reported the learning benefits within situated learning contexts, more research is needed to explore situated learning afforded by mobile devices, and the potential of this situated learning to influence learning in both positive and negative ways. Specifically regarding the situational affordances of mobile e-books, more research is needed that focuses on how having access to all required course texts and materials on a single, portable device is unique, and, more importantly, how this mobility affects student learning.

\section{F. Student and Instructor Views on the Learning Value of Social Texts Diverged}

The final major conclusion of this study pertained to the concept of a "social text," which relates to Research Subquestion C: what changes to mobile e-books do students want that would best support use of these devices for learning? Students described using their e-books in a multitude of social ways and said that they desired increased ability to be connected to their peers and to facilitate collaborative learning with their e-books, with instant messaging, discussion boards, note sharing, and comments.

Although the students all supported the use of social texts in their courses, the instructor held an opposing perspective. He expressed reservations that students openly interacting and sharing within the textbook would encourage shallow learning and proliferation of incorrect information, thus diminishing overall student learning. Related to this concern, he conveyed a desire to monitor discussions and information sharing among students. Additionally, he touted the textbook content's supremacy over information generated through student learning interactions.

However, the instructor's comments were based on hypothetical experiences. To determine whether his concerns are unfounded or not, more research is needed about instructor perspectives of more open and interactive instructional technologies, like the social e-textbook, after instructors have actually used them with students. This real-world experience would provide more authentic instructor perceptions of interactive e-books.

\section{E-BOOK TRANSITION UPDATE}

FSCJ planned to transition from paper-based textbooks to electronic textbooks for many of its 100and 200-level courses by the fall 2011 semester. As part of the college's SIRIUS Academics initiative, a college course design and textbook-publishing consortium, as of fall 2012 FSCJ no longer prints and sells paper-based versions of SIRIUS Academics course textbooks. The SIRIUS Academics initiative that was originally introduced to the college in 2003, as a college quality improvement plan, was intended to reduce overall textbook costs to students and to improve the quality of student learning experiences [11]. As a measure that reduces textbook costs to students and makes college education more affordable and accessible, students receive course textbooks in an entirely electronic format that can be used online and on mobile e-book reading devices, with the current price per book set at $\$ 48.00$. The transition was actually delayed to the spring 2012 semester, due in large part to difficulties associated with establishing a single sign on process for the registering and distributing of immediate access to the e-books. The single sign on process entailed connecting the college's registration, student portal, and e-book reader software CafeScribe so that the allocation of e-book course resources was immediate and seamless with the registration process.

\section{LIMITATIONS}

This collective case study was designed to explore the mobile e-book learning experiences within its situated boundaries. The study of each student case was carried out to further the understanding of the implementation of mobile e-books at a state college that is transitioning to e-books for its in-house 
published SIRIUS textbooks. The findings from this qualitative study were not intended to be generalized to other populations; rather, the purpose was to enhance understandings of the learning experiences of these students with the mobile e-books. By doing this, opportunities for further research were generated, as well as an enhanced understanding of how these students at FSCJ used ebooks for their learning.

Students who volunteered for this research self-selected into the study; therefore, there was an increased likelihood that they were already "early adopters" of technology. Additionally, most of the students that participated in the study were in their twenties. Younger students may have been more conformable with mobile technologies, due to their lifelong immersion in a world saturated with hitech devices exposure to these devices. Also, the students who did not use e-books were not studied and interviewed. This nonuser perspective may have contributed to the overall understanding of mobile e-book learning experiences within this bounded study. Future studies would also benefit from acquiring more heterogeneous subjects.

In-depth interviews with each of the students participants were conducted, open-ended question prompts designed to address their mobile e-book learning experiences. However, self-report data is not always a reliable indicator of true individual perspectives, feelings, and behaviors. Future studies on mobile e-book learning experiences will be beneficial in further enhancing the knowledgebase and educational leaders' understanding of student learning e-books.

\section{FUTURE RESEARCH}

The major recommendation for further research is based on the concept of the social textbook. Within this case study, students overwhelmingly wanted to see more interactive and collaborative learning opportunities within their e-books. The instructor did not support this type of learning environment, as he felt it would diminish the students' learning depth and remove his ability to control the learning discourse. Even though this study only provides a single faculty member's perspective, more inquiries are needed to explore the potential benefits and challenges of more open and interactive learning environments that are embedded within a course context, such as electronic textbooks. Moreover, how this type of learning environment would be received and used by instructors is largely unknown at this time and needs to be examined.

\section{ABOUT THE AUTHOR}

Jeff S. Kissinger is the Chief Learning Solutions Architect for Florida State College. In his position he leads the design and development team to create innovative learning solutions for diverse populations in higher education, corporate, and government contexts. Jeff has worked in many arenas of education and training including K-12, industry, and higher education. Jeff's passions are emerging instructional technologies, mobile learning, social media for learning, open learning resources, and global education issues. When he is not teaching or pondering learning, he is often found skateboarding or trying to plan a snowboard trip.

\section{REFERENCES}

1. U. S. Government Accountability Office. 2005. College textbooks: Enhanced offerings appear to drive recent price increases. Washington, DC: GAO.

2. http://www.gao.gov/new.items/d05806.pdf

3. EDUCAUSE. 7 things you should know about the evolution of the textbook. April 3, 2012, http://www.educause.edu/library/resources/7-things-you-should-know-about-evolutiontextbook

4. Brown, A. Northwest, McGraw-Hill e-book trial garners national media coverage. March 4, 2009, http://www.nwmissouri.edu/media/news/2009/03/090304mcgrawhill.htm

5. Princeton University. E-reader pilot program at Princeton, Fall 2009. Last modified October 27, 2010, http://www.princeton.edu/ereaderpilot/

6. Sannier, A. Please welcome ASU's newest freshman to campus: The Kindle, The Selfish Thought (blog). http://sannier.blogspot.com/2009/05/please-welcome-asu-newest-freshmanto.html 
7. Read, B. Northwest Missouri State U. tries e-book readers, with mixed results, The Chronicle of Higher Education, The Wired Campus blog).

http://chronicle.com/blogs/wiredcampus/northwest-missouri-state-u-tries-e-book-readerswith-mixed-results/4469

8. Johnson, L., R. Smith, H. Willis, A. Levine, and K. Haywood. The 2011 horizon report. Austin: The New Media Consortium, 2011. http://net.educause.edu/ir/library/pdf/hr2011.pdf

9. Johnson, L., S. Adams, M. Cummins. The NMC horizon report: 2012 higher education edition. 2012. Austin: The New Media Consortium. http://net.educause.edu/ir/library/pdf/HR2012.pdf

10. Sharples, M. Big issues in mobile learning: Report of a workshop by the kaleidoscope network of excellence mobile learning initiative. Nottingham: Learning Sciences Research Institute, 2007.

11. Sharples, M., Taylor, J. and Vavoula, G. Towards a theory of mobile learning. In Mobile technology: The future of learning in your hands, 58. Cape Town: mLearn, 2005. http://www.researchinlearningtechnology.net/index.php/rlt/article/view/14406/html

12. Florida State College at Jacksonville (FSCJ). About the SIRIUS Academics consortium. SIRIUS Academics. http://www.siriusacademics.org/about

13. Traxler, J. Institutional issues: Embedding and supporting. In Mobile learning: A handbook for educators and trainers. 175-86. London: Routledge, 2005.

14. Roschelle, J. Keynote paper: Unlocking the learning value of wireless mobile devices. Journal of Computer Assisted Living 19, no. 3: 260-72 (2003). doi: 10.1046/j.02664909.2003.00028.x

15. Leadbeater, C. Learning about personalization: How can we put the learner at the heart of the education system? London: Department for Education and Skills, 2004..

16. Plant, S. On the mobile: The effects of mobile telephones on social and individual life. 2001. http://classes.dma.ucla.edu/Winter03/104/docs/splant.pdf

17. Skinner, B. F. About behaviorism. New York: Knopf, 1974.

18. Brown, J. S., A. Collins, and P. Duguid. "Situated cognition and the culture of learning." Educational Researcher 18, no. 1 (1989): 32-42.

19. Greeno, J. G., A. M. Collins, and L. B. Resnick. Cognition and learning. In Handbook of educational psychology, 15-46. New York: Macmillan, 1996.

20. Piaget, J. Psychology of intelligence. Paterson, NJ: Littlfefield, Adams, 1969.

21. Eggen, P., and D. Kauchak. Educational psychology: Windows on classrooms. 6th ed. Upper Saddle River, NJ: Prentice Hall, 2007.

22. Patten, B., I. Arnedillo-Sánchez, and B. Tangney. Designing collaborative constructionist and contextual applications for handheld devices: Virtual learning? Computers \& Education 46, no. 3:294-3082006 (2006). doi: 10.1016/j.compedu.2005.11.011

23. Rogers, Y., S. Price, G. Fitzpatrick, R. Fleck, E. Harris, H. Smith, C. Randell, H. Muller, C. O'Malley, and D. Stanton. Ambient wood: Designing new forms of digital augmentation for learning outdoors. In Proceedings of the 2004 Conference on Interaction Design and Children: Building a community, 3-10. New York: Association for Computing Machinery (ACM), 2004.

24. Zurita, G., M. Nussbaum, and M. Sharples. Encouraging face-to-face collaborative learning through the use of handheld computers in the classroom. In Proceedings of Mobile HCI 2003, 193-208.Berlin: Springer-Verlag, 2003.

25. Miller, G. A. The magical number seven, plus or minus two: Some limits on your capacity for processing information. Psychology Review 63:81-97 (1956).

26. Baddeley, A. J. Working memory. Science, 255, no. 5044:556-9 (1992).

27. O'Malley, C., and D. S. Fraser. Literature review in learning with tangible technologies. Bristol, UK: Futurelab, 2004.

28. Doolittle, P., and G. Mariano. Working memory capacity and mobile multimedia learning environments: Individual differences in learning while mobile. Journal of Educational Multimedia and Hypermedia 17, no. 4:511-30 (2008).

29. Sweller, J. Cognitive load theory, learning difficulty, and instructional design. Learning and Instruction 4:295-312v (1994). doi: 10.1016/0959-4752(94)90003-5 
30. Shiffrim, R. M., and W. Schneider. Controlled and automatic human information processing: II. Perceptual learning, automatic attending, and a general theory. Psychological Review 84:127-90. (1977).

31. Flavell, J. H. Metacognitive aspects of problem solving. In The nature of intelligence, 23136. Hillsdale, NJ: Lawrence Erlbaum, 1976.

32. Santrock, J. W. Educational psychology. 4th ed. Boston: McGraw-Hill, 2009.

33. Schunk, D. H., P. R. Pintrich, and J. L. Meece. Motivation in education: Theory, research, and applications. 3rd ed. Upper Saddle Ridge, NJ: Prentice Hall, 2008.

34. Bandura, A. Social foundations of thought and action. Greenwich, CT: JAI Press, 1986.

35. Bandura, A. Self-efficacy: The exercise of control. New York: Freeman, 1997.

36. Waycott, J. PDA as lifelong learning tools: An activity theory based analysis. Learning, Media \& Technology, 30, no. 2:107-30 (2005).

37. Campbell, N. K., and G. Hackett. The effects of mathematics task performance on math self-efficacy and task interest. Journal of Vocational Behavior, 28:149-62 (1986).

38. Wood, R. E., and E. A. Locke. The relation of self-efficacy and grade goals to academic performance. Educational and Psychological Measurement, 47:1013-24 (1987).

39. Compeau, D. R., and C. A. Higgins. Computer self-efficacy: Development of a measure and initial test. MIS Quarterly, 19, no. 2:189-211 (1995).

40. Murphy, C., D. Coover, and S. Owen. Development and validation of the computer selfefficacy scale. Educational and Psychological Measurement, 49, no. 4:893-99 (1989).

41. Wang, Y. S., and H. Y. Wang. Developing and validating an instrument measuring mobile computing self-efficacy. CyberPsychology \& Behavior, 11, no. 4:405-13 (2008).

42. Atkinson, J. W. Motivational determinants of risk-taking behavior. Psychological Review, 64:359-72 (1957).

43. Wigfield, A., and J. S. Eccles. Expectancy-value theory of achievement motivation. Contemporary Educational Psychology, 25, no. 1:68-81 (2000).

44. Ryan, R. M., and E. L. Deci. Self-determination theory and the facilitation of intrinsic motivation, social development, and well-being. American Psychologist, 55, no. 1:68-78 (2000).

45. Engeström, Y. Learning by expanding: An activity-theoretical approach to developmental research. Helsinki: Orienta-Konsultit Oy, 1987.

46. Engeström, Y. Expansive learning at work: Toward an activity theoretical reconceptualization. Journal of Education and Work, 14, no. 1: 133-56 (2001).

47. Vygotsky, L. S. Mind and society: The development of higher mental processes. Cambridge: Harvard University Press, 1978.

48. Lave, J., and E. Wenger. Situated learning: Legitimate peripheral participation. Cambridge: Cambridge University Press, 1991.

49. Anderson, J. R., L. M. Reder, and H. A. Simon. Situated learning and education. Educational Researcher, 25, no. 4:5-11 (1996).

50. Kukulska-Hume, A., and J. Traxler, eds. Mobile learning: A handbook for educators and trainers. London: Routledge, (2005).

51. Ryu, H., and D. Parsons. Designing learning activities with mobile technologies. In Innovative mobile learning: Techniques and technologies. Hershey, PA: Information Science Reference (IGI Global), (2009) 1-20.

52. Kossen, J. S. When e-learning becomes m-learning. E-learning, Friday, June 1, 2001. http://zatz.com/computingunplugged/article/when-e-learning-becomes-m-learning/

53. Laouris, Y., and N. Eteokleous. We need an educationally relevant definition of mobile learning. In Mobile technology: The future of learning in your hands, mLearn 2005 book of abstracts, 28. Cape Town: mLearn, 2005.

54. Quinn, C. 2000. mLearning: Mobile, wireless, in-your-pocket learning. LiNE Zine. http://www.linezine.com/2.1/features/cqmmwiyp.htm

55. Traxler, J. Learning in a mobile age. International Journal of Mobile and Blended Learning, 1, no. 1:132 (2009). 
56. Cheung, W. S., and K. F. Hew. A review of research methodologies used in studies on mobile handheld devices in k-12 and higher education settings. Australasian Journal of Educational Technology, 25, no. 2:152-83 (2009).

57. Hughes, J. The role of teacher knowledge and learning experiences in forming technologyintegrated pedagogy. Journal of Technology and Teacher Education, 13, no. 2:277-302 (2005).

58. Danaher, P., R. Gururajan, and A. Hafeez-Baig. Transforming the practice of mobile learning: Promoting pedagogical innovation through educational principles and strategies that work. In Innovative mobile learning: Techniques and technologies, 21-46. Hershey, PA: Information Science Reference (IGI Global), 2009.

59. Motiwalla, L. F. Mobile learning: A framework and evaluation. Computers \& Education, 49, no. 3:581-96 (2007).

60. Sharples, M. The design of personal mobile technologies for lifelong learning. Computers \& Education, 34, no. 3-4:177-93 (2000).

61. Sharples, M., D. Corlett, and O. Westmancott. The design and implementation of a mobile learning resource. Personal and Ubiquitous Computing, 6, no. 3:220-34 (2002).

62. Sharples, M., C. O'Malley, and J. Taylor. A study of mobile learning as part of everyday learning. In Mobile elarning anytime everywhere: A book of papers from mLearn 2004, $211-$ 12. Rome: mLearn, 2004.

63. Lincoln, Y. S., and E. G. Guba. Naturalistic inquiry. Thousand Oaks, CA: Sage, 1985.

64. Stake, R. E. Identification of the case. In Handbook of qualitative research. Thousand Oaks, CA: Sage, 1994. 236-47.

65. Yin, R. K. Case study research: Design and methods. 2nd ed. Thousand Oaks, CA: Sage, 1994.

66. Yin, R. K. Case study research: Design and methods. 4th ed. Thousand Oaks, CA: Sage, 2009.

67. Patton, M. Q. Qualitative research and evaluation methods. Thousand Oaks, CA: Sage, 2002.

68. Corbin, J. M., and A. L. Strauss. Basics of qualitative research. 3rd ed. London: Sage, 2008.

69. Wexelbaum, R., and P. Miltenoff. Challenges to E-Reader Adoption in Academic Libraries. The Reference Librarian, 53, no. 3:270-83 (2012). 